\begin{tabular}{|l|l|l|l|l|l|} 
J. Tek. Ling & Vol.11 & No.3 & Hal. 331 - 339 & Jakarta, September 2010 & ISSN 1441-318X \\
\hline
\end{tabular}

\title{
EVALUASI LAHAN UNTUK ZONASI KOMODITAS UNGGGULAN PERTANIAN KASUS KAWASAN RAWA PASANG SURUT KABUPATEN BATOLA
}

\author{
Mubekti \\ Pusat Teknologi Inventarisasi Sumberdaya Alam - TPSA \\ Badan Pengkajian dan Penerapan Teknologi
}

\begin{abstract}
The evaluation of agricultural commodity zoning is implemented on tidal swamp area in Batola District, South Kalimantan Province. In fact, the quality of land varies from one place to the others due to the presence of limiting factors in it. Therefore a study of land suitability is essentially needed before utilizing land for cultivation. The method used in the study refers to FAO procedure and Soil Research Institute as well. A brief explanation of land resources evaluation, land suitability and commodities zoning for food crop, horticulture, and plantation crop is presented in the methodology. Then, the results of land characterization and suitability classification in Batola District are discussed, so that, more understanding in respect to land properties and quality is derived. There are three groups of soils is found the study area, namely peat soils, marine soils and pluviatile soils. By nature those soils have several limiting factors, i.e. drainage (flooding), acidity, sulphate potential, salinity, and low fertility. The highest grade of suitable land in Batola is only S2 (moderately suitable), and the largest area is classified as S3 (marginally suitable) for all analyzed cultivation. Since, the results of land suitability were derived then the commodities zoning were conducted. Water managing, liming, and fertilizing are definitely needed for land development and land reclamation.
\end{abstract}

Key words: land evaluation, commodities zoning, GIS, agriculture

\section{PENDAHULUAN}

\subsection{Latar Belakang}

Tanah merupakan sumber daya fisik wilayah utama yang sangat penting untuk diperhatikan dalam perencanaan tataguna tanah. Bersama dengan sumber daya fisik wilayah yang lain, seperti iklim, topografi, geologi, dan lain-lain, sifat tanah sangat menentukan potensinya untuk berbagai jenis penggunaan ${ }^{1}$. Karakterisasi sumber daya lahan berdasarkan sifat-sifat fisik tersebut akan menentukan nilai atau kelas suatu lahan apabila akan dimanfaatkan untuk penggunaan tertentu, misalnya untuk pengembangan bidang pertanian.

Potensi sumberdaya lahan cukup beragam karena adanya perbedaan iklim, bahan induk tanah, dan topografi/relief. Keragaman potensi sumberdaya Iahan tersebut mengindikasikan perlunya suatu perencanaan penggunaan lahan yang tepat, optimal dan berkelanjutan. Untuk mendukung perencanaan tersebut diperlukan data dan informasi sumberdaya lahan yang meliputi distribusi atau luas penyebaran, potensi dan kendala pengembangan serta teknologi pengelolaan lahannya sesuai dengan sifat dan karakteristik lahannya. 
Evaluasi Iahan merupakan suatu proses penilaian potensi suatu lahan untuk penggunaan-penggunaan tertentu. Hasil evaluasi lahan digambarkan dalam bentuk peta sebagai dasar untuk perencanaan tataguna lahan yang rasional, sehingga dapat digunakan secara optimal dan lestari. Penggunaan lahan yang tidak rasional dalam arti tidak sesuai dengan kemampuannya, di samping dapat menimbulkan terjadinya kerusakan juga akan meningkatkan masalah kemiskinan dan masalah sosial lain.

Suatu kenyataan, bahwa lahan di Kabupaten Barito Kuala (Batola) mempunyai banyak kendala apabila akan dimanfaatkan sebagai kawasan budidaya pertanian. Lahan gambut (Histosol) yang berada di Kabupaten ini pada umumnya mempunyai keasaman yang tinggi sehingga akan menjadi hambatan bagi pertumbuhan tanaman. Tanah sulfat masam yang terdapat disinipun mempunyai kemasaman yang tinggi ditambah dengan potensi kandungan besi yang berlebihan akan bersifat racun bagi tanaman. Oleh karena itu, informasi mengenai kondisi fisik serta kendala-kendala yang mungkin timbul sangat diperlukan apabila akan dimanfaatkan untuk pengembangan pertanian.

Pembangunan bidang pertanian di Kabupaten Batola diwujudkan dalam 'Program Agropolitan' yang tercantum dalam SK Bupati nomor: 369 tahun 2003. Kegiatan pembangunan pertanian tersebut diarahkan untuk mendukung keberadaan Kabupaten Barito Kuala sebagai daerah penunjang program ketahanan pangan nasional, serta untuk mengurangi angka pengangguran melalui penyerapan tenaga kerja di sektor pertanian.

Teknologi Computer Mapping dan GIS (Geographical Information System) serta pemanfaatan teknologi Remote Sensing, diharapkan berpotensi untuk menunjang pelaksanaan identifikasi potensi sumber daya lahan. Dengan pemanfaatan teknologi GIS diharapkan diperoleh informasi terkini, akurat dan cepat mengenai sumber daya lahan pertanian. Informasi inilah yang nantinya digunakan untuk membuat pilihanpilihan alternatif pengelolaan lahan pertanian yang rasional dan berkelanjutan, sehingga upaya menciptakan ketahanan pangan yang stabil dapat terwujud.

\subsection{Tujuan dan Sasaran}

Kegiatan studi evaluasi lahan untukzonasi komoditas unggulan pertanian bertujuan untuk menyediakan informasi mengenai penyebaran dan luasan areal yang sesuai untuk budidaya komoditas pertanian unggulan di Kabupaten Barito Kuala. Komoditas unggulan tersebut meliputi komoditas pangan, hortikultura, dan perkebunan.

\section{METODOLOGI}

Tahapan yang dilakukan dalam evaluasi lahan untuk zonasi komoditas pertanian meliputi: (1) evaluasi kualitas lahan melalui pemetaan satuan lahan, (2) evaluasi kesesuaian lahan untuk masingmasing komoditas berdasarkan faktor-faktor pembatas lahan, dan (3) Zonasi (pewilayahan) komoditas bedasarkan kelompok pangan, hortikultura, dan perkebunan.

\subsection{Evaluasi Kualitas Lahan}

Tujuan evaluasi kualitas lahan adalah mengevaluasi sifat-sifat fisik lahan yang diwujudkan dalam peta satuan lahan. Peta satuan Iahan merupakan dasar dalam penilaian kesesuaian lahan. Peta ini dibangun dari analisis dan interpretasi data DEM-SRTM, Citra satelit Landsat TM, dan didukung peta geologi skala 1:250.000 serta data atau peta hasil penelitian terdahulu.

Peta lereng dan dan bentuk wilayah dianalisis dari SRTM. Peta satuan lahan/ tanah dari hasil kegiatan terdahulu pada berbagai skala peta digunakan sebagai referensi terutama dalam kelompok fisiografi dan klasifikasi tanah serta data basenya. Kegiatan ini lebih mengutamakan deskwork, sedangkan pengamatan lapangan 
dilakukan secara terbatas pada daerah yang asesibilitasnya cukup baik.

\subsection{Evaluasi Kesesuaian lahan}

Klasifikasi kesesuaian lahan yang dilakukan untuk penelitian ini menggunakan kriteria hasil modifikasi yang dikemukakan dalam Atlas Format Procedure ${ }^{2}$ dan Petunjuk Teknis Evaluasi Lahan ${ }^{3)}$. Evaluasi kesesuaian lahan dilakukan dengan mengevaluasi sifatsifat fisik yang terdapat peta satuan lahan dan dicocokkan dengan persyaratan tumbuh komoditas unggulan yang dinilai, sehingga dapat ditentukan kelas kesesuaian dari setiap unit lahan. kelas kesesuaian lahan dikelompokkan dalam katagori: (1) Kelas S1 : sangat sesuai (highly suitable, (2) Kelas S2 : cukup sesuai ( moderately suitable), (3) Kelas S3 : sesuai marginal (marginally suitable), (4) Kelas N : tidak sesuai (not suitable).

Penentuan kelas ditentukan oleh faktor pembatas yang paling berat. Misalnya berdasarkan variabel drainase suatu unit lahan masuk kelas S2, tetapi dari variabel kedalaman gambut masuk kelas S3, maka unit lahan tersebut dimasukkan kedalam kelas S3 dengan faktor pembatas utama adalah tekstur.

\subsection{Zonasi Komoditas}

Zonasi komoditas pertanian unggulan disusun berdasarkan hasil evaluasi lahan yang telah dibahas sebelumnya. Analisis zonasi dilakukan terhadap tiga kelompok komoditas, yaitu (1) Komoditas pangan terdiri dari tanaman padi dan ubi kayu, (2) Komoditas Hortikultura terdiri dari tanaman jeruk, rambutan dan nenas, dan (3) Komoditas Perkebunan terdiri dari kalapa dalam, kelapa sawit dan karet.

Komoditas hanya dibatasi pada tanaman unggulan saja, yaitu tanaman yang mempunyai luasan, tingkat produksi serta mempunyai prospek yang tinggi. Untuk menyusun peta zonasi komoditas unggulan dilakukan dengan menentukan kombinasi tanaman unggulan berdasarkan kelas kesesuaian lahan hasil penilaian untuk menentukan potensinya dan kemudian mengoverlaikan hasil kombinasi kesesuian tersebut.

\section{KONDISI LAHAN DAN PERTANIAN}

\subsection{Kondisi Fisik Lahan}

Kabupaten Barito Kuala sebagian besar wilayahnya dikelilingi sungai dan rawa. Kondisi ini menyebabkan tanah daerah ini mengandung lahan gambut. Tingkat keasaman tanah di sana mencapai $\mathrm{pH}$ 3-5. Wilayah ini terdiri dari dua jenis tanah yang dominan, yaitu Aluvial sebesar 59,46\% dan selebihnya sekitar 40,54 $\%$ merupakan Organosol Glei Humus yang sebagian merupakan daerah yang tergenang terus menerus.

Kondisi drainase di Kabupaten Barito Kuala menjadi kendala utama dalam pengembangan pertanian. Areal yang tergenang terus menerus mencapai 60,38 $\%$ dari seluruh areal yang tersebar pada setiap kecamatan. Sedangkan areal yang tergenang periodik, meliputi $35,68 \%$ dan areal yang tidak pernah tergenang hanya seluas 3,94 \% wilayah tersebar pada Kecamatan Anjir Muara, Anjir Pasar, Alalak, Belawang, Bakumpai dan Tabukan.

Pengaruh luapan pasang surut terhadap lahan dapat dibagi menjadi 4 tipe ${ }^{4}$, yaitu (1) Tipe Luapan A, yaitu meliputi wilayah-wilayah yang dapat terluapi oleh air pasang, baik oleh pasang besar (tunggal) ataupun oleh pasang kecil (ganda), (2) Tipe Luapan B, yaitu meliputi wilayah-wilayah yang hanya dapat terluapi oleh air pasang besar (tunggal) saja, sedangkan pada pasang kecil air tidak dapat meluapi lahan, (3) Tipe Luapan C, yaitu meliputi wilayah-wilayah yang tidak dapat terluapi air pasang, tetapi air pasang mempengaruhi kedalaman muka air tanah kurang dari $50 \mathrm{~cm}$ dari permukaan tanah, dan (4) Tipe Luapan D, yaitu meliputi wilayahwilayah yang sama sekali tidak terluapi oleh air pasang, air pasang hanya mempengaruhi permukaan air tanah pada kedalaman lebih dari $50 \mathrm{~cm}$ dari permukaan air tanah. 
Kabupaten Barito Kuala dialiri oleh beberapa sungai antara lain sungai Barito, sungai Negara, sungai Alalak dan handilhandil. Sungai-sungai besar yang terdapat di wilayah Kabupaten Barito Kuala dan berfungsi sebagai transportasi dan drainase adalah : (1) Sungai Barito, (2) Sungai Negara, (3) Sungai Kapuas, (4) Anjir Serapat, (5) Anjir Tamban, (6) Sungai Alalak, dan (7) Sungai Puntik.

\subsection{Penggunaan Lahan}

Luasan Kabupaten Batola sekitar 2400 kilometer persegi dan sebagian besar penduduknya hidup dan tinggal di pedesaan. Wilayah ini merupakan daerah pasang surut, oleh karena itu masyarakat umumnya mengandalkan pertanian sebagai mata pencaharian, di samping sebagai nelayan maupun buruh pabrik.

Tabel 1. menyajikan data penggunaan lahan tahun 2007. Dalam Tabel menunjukkan bahwa sebagian besar wilayah, yaitu 133.065 hektar atau lebih dari $50 \%$, telah dimanfaatkan sebagai lahan sawah walaupun sebagian persawahan untuk sementara tidak diusahakan. Sedangkan lahan bukan sawah pada umumnya dimanfaatkan untuk pekarangan, tegalan, kebun, ternak dan lain-lain.

Tabel 1. Luas Wilayah Menurut Jenis Penggunaan Tanah

\begin{tabular}{|l|l|}
\hline \multicolumn{1}{|c|}{$\begin{array}{c}\text { Jenis } \\
\text { Penggunaan Tanah }\end{array}$} & Luas Tanah (Ha) \\
\hline Lahan Sawah & \\
\hline 1. Pasang Surut & 109.560 \\
\hline 2. Tidak diusahakan & 23.505 \\
\hline Bukan Lahan Sawah & \\
\hline 1. Lahan Pekarangan & 15.758 \\
\hline 2. Tegalan/Kebun & 13.308 \\
\hline 3. Ladang/Huma & 1.889 \\
\hline 4. Penggembalaan & 10.928 \\
\hline 5. Tidak Diusahakan & 11.769 \\
\hline 6. Lain-lain & 53.627 \\
\hline JUMLAH & $\mathbf{2 4 0 . 3 5 4}$ \\
\hline
\end{tabular}

Diolah dari : Barito Kuala Dalam Angka 2008

\subsection{Pertanian}

Pada tahun 2000 sektor pertanian menyumbang Rp 623 milyar atau 25,3 persen dari total kegiatan ekonomi Kabupaten Barito Kuala. Dari jumlah itu, tanaman bahan pangan menduduki peringkat tertinggi $(21,1$ persen) dengan padi sebagai komoditas andalan.

Menurut data Dinas Pertanian Kabupaten Batola (2008) luas panen padi mencapai 94.687 ha pada tahun 2007. Kabupaten Barito Kuala merupakan sentra produksi padi andalan Kalimantan Selatan dengan kontribusi berkisar antara $17,11 \%-18,15 \%$. Sebagian besar produksi padi berasal dari Kecamatan Anjir Muara, dengan jenis padi unggulan Siam Unus ${ }^{5}$.

Selain padi, buah-buahan juga menjadi andalan, diantaranya jeruk, nenas, mangga, dan rambutan. Jeruk adalah salah satu tanaman hortikultura yang diunggulkan. Luas lahan jeruk mencapai 15.974 hektar. Pemerintah Daerah sedang mengupayakan peningkatan jumlah dan kualitas jeruk yang dikenal dengan nama Jeruk Siam Banjar. Produksi jeruk mengalami peningkatan, yang mana produksi menjadi 85.235 kuintal tahun 2000, meningkat 48 persen dari tahun sebelumnya.

Komoditas perkebunan yang sedang dikembangkan di Kabupaten Barito Kuala adalah kelapa dalam, kelapa hibrida, karet, kelapa sawit, kopi cengkeh, sagu, purun danau, pinang, sengon dan rotan. Dalam kajian zonasi komoditas unggulan ini, komoditas yang akan dievaluasi adalah kelapa dalam, karet dan kelapa sawit yang diperkirakan mempunyai prospek yang baik dalam waktu yang akan datang.

\section{HASIL DAN PEMBAHASAN}

\subsection{Satuan Lahan}

Berdasarkan hasil interpretasi, pengamatan lapang, hasil studi sebelumnya ${ }^{6,7)}$ dan didukung data hasil analisis laboratorium, 
Kabupaten Batola terdiri dari 3 fisiografi, yaitu formasi gambut, Formasi endapan Marin, dan Formasi endapan Sungai serta terbagi menjadi 18 satuan lahan. Gambar 1., adalah peta hasil analisis satuan lahan. Formasi gambut terdiri dari tanah gambut di rawa payau dan tanah gambut di rawa air tawar. Endapan-endapan marin terdiri dari endapan dekat pantai dengan reaksi agak asam sampai akalin, endapan yang mempunyai potensi sulfat masam, dan endapan yang mempunyai kemasaman tinggi sampai sangat tinggi. Endapan-endapan sungai terdiri dari endapan bekas meander sungai dan endapan pada tanggul-tanggul sungai.

\section{1) Formasi Gambut}

Pada formasi gambut terdapat 4 (empat) satuan lahan, yaitu Hb.h/f, Hf.h, Hf.h, dan Hf.h/s. Hb.h/f adalah satuan lahan dari komlek tanah gambut dengan tingkat dekomposisi hemik sampai saprik dibawah genangan air payau dan reaksi tanah agak masam sampai netral. Luasan satuan lahan ini mencapai 5.950 hektar tersebar di sebelah selatan Batola, yaitu di Kecamatan Tabunganen. Hf.h dan Hf.s merupakan satuan lahan dari tanah gambut topogenik dengan tingkat dekomposisi hemik dan saprik. Satuan lahan ini menempati cekungan-cekungan kecil sekitar Jelapat dan selatan anjir Tamban dengan kedalaman berkisar antara 50 sampai $70 \mathrm{~cm}$ dan $\mathrm{pH}$ rendah. Luasan Iahan ini adalah 2.849 hektar.

Hf.h/s merupakan satuan lahan gambut ombrogenik dengan tingkat dekomposisi hemist dan saprist di bawah rawa air tawar dengan rekasi tanah masam sampai sangat masam. Satuan lahan ini menempati pusat cekungan-cekungan berupa kubah-kubah gambut, terutama sebagian besar terletak di sebelah utara anjir Serapat dan sebagian kecil di sebelah selatan anjir Serapat. Total luasan satuan lahan ini cukup luas, yaitu 47.021 hektar $(15,7 \%)$.

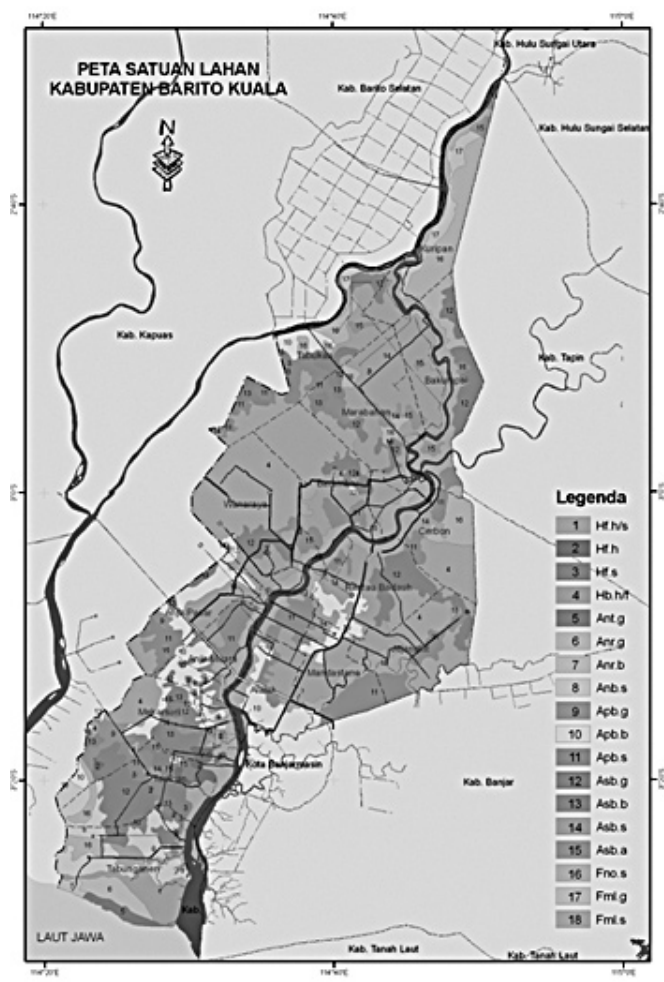

Gambar 1. Peta Satuan Lahan Kabupaten Batola

\section{2) Formasi Endapan Marin}

Satuan lahan yang dibentuk dari formasi endapan-endapan marin dapat dibagi menjadi tiga bagian. Pertama satuan lahan yang dibentuk dari endapan liat masif bereaksi netral sampai alkalin didaerah sekitar pantai terdiri dari satuan lahan Ant.g, Anr.g, Anr.b, dan Anb.s. Perbedaan dari masing-masing satuan lahan ini adalah lokasi pengendapannya. Ant.g terletak pada strip sempit sepanjang pantai, sedangkan Anr.g, Anr.b terletak pada punggung-punggung pantai yang berasosiasi dengan cekungancekungan. Satuan lahan Anb.s. terletak di cekungan pada zona pasang surut muda. Anb.s. merupakan satuan lahan yang paling luas yaitu mencapai 10.750 hektar.

Kedua adalah satuan Iahan pada cekungan yang mempunyai potensi sulfat masam, yaitu terdiri dari satuan-satuan lahan Apb.g, Apb.b, dan Apb.s. Reaksi tanah pada ketiga satuan lahan tersebut berkisar 
dari masam sampai sangat masam. Apb.g merupakan satuan lahan paling sempit luasannya dengan $\mathrm{pH}$ berkisar antara 4,65,4. Apb.b mempunyai luasan 22.294 hektar dengan reaksi tanah masam sampai sangat masam karena sulfat masam potensial sudah sedikit mengalami oksidasi. Sedangkan Apb.s merupakan satuan lahan terluas pada kelompok ini, yaitu menempati luasan 31.331 hektar terutama tersebar pada zona transisi tanggul sungai dan pusat cekungan mulai dari bagian selatan sampai dengan bagian utara Kabupaten.

Ketiga adalah satuan lahan yang terletak pada cekungan-cekungan dan mempunyai kandungan sulfat masam aktual dengan kemasaman tinggi sampai dengan

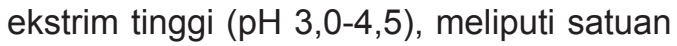
Iahan Asb.g, Asb.b, Asb.s, dan Asb.a. Pada umumnya lahan-lahan ini sudah dimanfaatkan untuk budidaya pertanian dan perkebunan. Asb.s merupakan satuan lahan sulfat masam aktual yang mempunyai luasan paling besar, yaitu 57.097 hektar. Sedangkan Asb.a merupakan satuan lahan sulfat masam aktual dengan kemasaman ekstrim tinggi bersumber dari oksidasi mineral pirit.

\section{3) Formasi Endapan Sungai}

Satuan lahan dari endapan sungai terdiri dari Fno.s, Fml.g, dan Fml.s. Fn.s merupakan satuan lahan pada bekas meander sungai dengan luasan 19.115 hektar dan reaksi tanah bervariasi antara 4,4 sampai dengan 6,7. Fml.s merupakan satuan lahan endapan sungai yang paling luas, yaitu mencapai luasan 49.191 hektar. Satuan lahan ini terbentuk pada tanggultanggul sungai terutama pada sungai-sungai Barito, Alalak, dan sungai besar lainnya.

\subsection{Kesesuaian Lahan}

Pada kegiatan/penelitian ini komoditas yang dinilai kelas kesesuaian lahannya adalah komoditas unggulan setempat, sedangkan komoditas yang tidak diunggulkan oleh daerah tidak dinilai. Namun demikian tidak berarti bahwa komoditas yang bukan unggulan tidak sesuai, tetapi ada kemungkinan sesuai pula namun tidak disajikan dalam hasil penelitian ini.

Hasil evaluasi kesesuaian lahan untuk beberapa usaha pertanian menujukkan, bahwa lahan yang tersebar di Kabupaten Batola tidak ada yang dikatagorikan sebagai kelas S1 untuk semua jenis usaha.

Tabel 2. menunjukkan bahwa sebahagian besar lahan di Batola masuk katagori sesuai marginal untuk budidaya tanaman pangan, yaitu 198.012 hektar untuk padi dan 156.344 hektar untuk ubi kayu. Sebagian kecil masuk katagori cukup sesuai untuk padi, yaitu 3.118 hektar, sedangkan yang lainnya masuk katagori tidak sesuai.

Analisis kesesuaian lahan untuk komoditas hortikultura dibatasi pada tanaman unggulan buah-buahan yang terdiri dari jeruk, rambutan, dan nenas. Diantara tanaman hortikultura yang mempunyai daya adaptasi paling tinggi terhadap tanah rawa Batola adalah tanaman nenas.

Tabel 2. Hasil Ekstraksi Luasan Kesesuaian Lahan untuk Komoditas Unggulan di Batola

\begin{tabular}{|l|c|c|c|c|}
\hline \multirow{4}{*}{ Komo-ditas } & \multicolumn{3}{|c|}{ Kelas Kesesuaian (ha) } & \multirow{2}{*}{$\begin{array}{c}\text { Total } \\
\text { Luasan }\end{array}$} \\
\cline { 2 - 4 } & S2 & S3 & N & \\
\hline Pangan & 3.118 & 198.012 & 39.233 & 240.354 \\
\hline Padi & & 156.344 & 84.010 & 240.354 \\
\hline Ubi Kayu & 3.118 & 96.978 & 140.258 & 240.354 \\
\hline Hortikultura & 3.118 & 196.974 & 40.262 & 240.354 \\
\hline Jeruk & 61.121 & 138.971 & 40.262 & 240.354 \\
\hline Rambutan & \multicolumn{5}{|l}{} \\
\hline Nenas & 73.643 & 137.720 & 28.991 & 240.354 \\
\hline Perkebunan & 61.121 & 152.527 & 26.706 & 240.354 \\
\hline $\begin{array}{l}\text { Kelapa } \\
\text { Dalam }\end{array}$ & 61.121 & 152.527 & 26.706 & 240.354 \\
\hline Sawit & &
\end{tabular}

Hal tersebut ditunjukkan oleh luasan lahan yang masuk katagori cukup sesuai, yaitu 61.121 hektar untuk nenas, sedangkan untuk rambutan dan jeruk lebih kecil luasannya. Sebagian besar lahan yang lain masuk katagori 
sesuai marginal atau tidak sesuai.

Tanaman perkebunan mempunyai daya adaptasi lebih baik terhadap lahan rawa pasang surut dibandingkan dengan tanaman pangan dan hortikultura. Hal tersebut dapat dilihat dalam Tabel 2, dimana lahan yang masuk katagori cukup sesuai mempunyai luasan yang relatif besar untuk ketiga komoditas perkebunan.

Pada umumnya faktor pembatas utama lahan rawa pasang surut di Batola adalah genangan air, kemasaman tanah yang tinggi, ketebalan gambut, serta bahaya racun besi dan aluminium.

\subsection{Zonasi Komoditas Pertanian Unggulan}

Zonasi komoditas unggulan tanaman pangan, hortikultura, dan perkebunan dilakukan dengan mengkombinasikan hasil analisis kesesuaian lahan untuk tanaman padi dan ubi kayu dan kemudian ditentukan potensinya. Analisis zonasi dilakukan terhadap tiga kelompok komoditas, yaitu (1) Komoditas pangan terdiri dari tanaman padi dan ubi kayu, (2) Komoditas Hortikulturn terdiri dari tanaman jeruk, rambutan dan nenas, dan (3). Komoditas Perkebunan terdiri dari kalapa dalam, kelapa sawit dan karet. Kombinasi kesesuaian dan potensinya adalah sebagai berikut:

Tabel 3. Komoditas Perkebunan kelapa sawit dan karet

\begin{tabular}{|c|c|c|}
\hline $\begin{array}{l}\text { Kode } \\
\text { Pangan }\end{array}$ & $\begin{array}{l}\text { Kesesuaian dan } \\
\text { Komoditas }\end{array}$ & Potensi \\
\hline P1 & S2-Padi, S3-Ubikayu & $\begin{array}{l}\text { rendah- } \\
\text { sedang }\end{array}$ \\
\hline P2 & S3-padi, S3-ubi kayu & rendah \\
\hline P3 & S3-padi & rendah \\
\hline $\mathrm{N}$ & N-komoditas pangan & $\begin{array}{l}\text { tidak } \\
\text { berpotensi }\end{array}$ \\
\hline \multicolumn{3}{|l|}{ Hortikultura } \\
\hline $\mathrm{H} 1$ & $\begin{array}{l}\text { S2-jeruk, S3- } \\
\text { rambutan, S3- nenas }\end{array}$ & sedang \\
\hline $\mathrm{H} 2$ & $\begin{array}{l}\text { S2-nenas, S3- } \\
\text { Rambutan, S3-Jeruk }\end{array}$ & $\begin{array}{l}\text { Rendah- } \\
\text { sedang }\end{array}$ \\
\hline
\end{tabular}

\begin{tabular}{|c|c|c|}
\hline $\begin{array}{l}\text { Kode } \\
\text { Pangan }\end{array}$ & $\begin{array}{l}\text { Kesesuaian dan } \\
\text { Komoditas }\end{array}$ & Potensi \\
\hline $\mathrm{H} 3$ & $\begin{array}{l}\text { S3-jeruk, S3- } \\
\text { rambutan, S3-nenas }\end{array}$ & rendah \\
\hline $\mathrm{H} 4$ & $\begin{array}{l}\text { S3-nenas, S3- } \\
\text { rambutan }\end{array}$ & rendah \\
\hline $\mathrm{N}$ & $\begin{array}{l}\mathrm{N} \text { - komoditas } \\
\text { hortikultura }\end{array}$ & $\begin{array}{l}\text { Tidak } \\
\text { berpotensi }\end{array}$ \\
\hline \multicolumn{3}{|l|}{ Perkebunan } \\
\hline K1 & $\begin{array}{l}\text { S2-kelapa dalam, } \\
\text { S2-kelapa sawit, } \\
\text { S2-karet }\end{array}$ & sedang \\
\hline K2 & $\begin{array}{l}\text { S2-kelapan dalam, } \\
\text { S3-Kelapa Sawit, } \\
\text { S3-Karet }\end{array}$ & $\begin{array}{l}\text { Rendah- } \\
\text { sedang }\end{array}$ \\
\hline K3 & $\begin{array}{l}\text { S3-kelapa dalam, } \\
\text { S3-kelapa sawit, } \\
\text { S3-karet }\end{array}$ & rendah \\
\hline K4 & $\begin{array}{l}\text { S3-karet, S3-kelapa } \\
\text { sawit }\end{array}$ & rendah \\
\hline $\mathrm{N}$ & $\begin{array}{l}\text { N-komoditas } \\
\text { perkebunan }\end{array}$ & $\begin{array}{l}\text { Tidak } \\
\text { berpotensi }\end{array}$ \\
\hline
\end{tabular}

Setelah ditentukan kombinasi dan potensinya, tahap berikutnya adalah melakukan overlay antara kombinasi tanaman dan potensinya. Proses overlai menghasilkan peta zonasi komoditas seperti yang terlihat dalam Gambar 2. untuk komoditas pangan, Gambar 3. untuk komoditas hortikultura dan Gambar 4. untuk tanaman perkebunan. Sedangkan ekstraksi luasan masing zona disampaikan dalam Tabel 3.

Seperti yang terlihat dalam Gambar 2., bahwa sebagian besar zonasi komoditas pangan masuk katagori potensi rendah (153.229 ha) dan tersebar hampir merata di seluruh Kabupaten. Sedangkan zonasi pangan dengan potensi rendah sampai sedang terutama tersebar di kecamatan Mekarsari, Anjir Muara dan Anjir Pasar dengan luasan 3.117 ha (Tabel 3). Tanah-tanah sulfat masam aktual yang mempunyai $\mathrm{pH}$ sangat rendah masuk dalam katagori tidak berpotensi untuk komoditas pangan.

Hasil zonasi komoditas hortikultura menunjukkan bahwa wilayah dengan potensi sedang mencapai luasan 3.118 ha dengan penyebaran terutama di Kecamatan 
Mekarsari, dan sebagian di Kecamatan Anjir Muara dan Anjir Pasar. Wilayah ini termasuk dalam tanah-tanah sulfat masam potensial yang belum mengalami oksidasi.

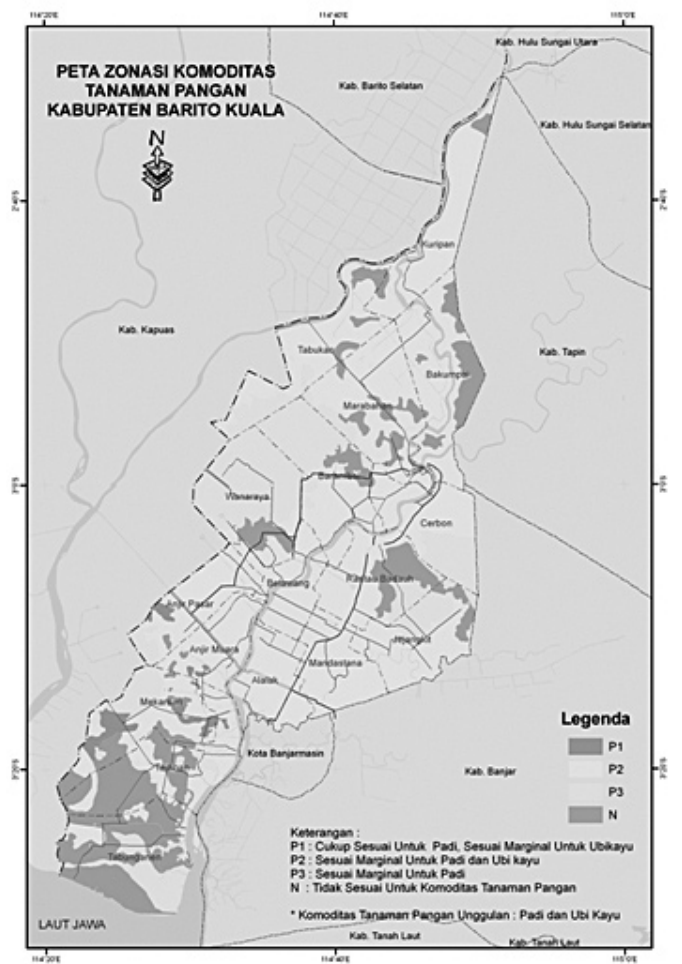

Gambar 2. Zonasi Komoditas Pangan

Zona dengan potensi dari rendah sampai sedang tersebar sepanjang tanggul aliran sungai Barito dan sungai Alalak mencapai luasan 58.003 ha. Zona potensi rendah dijumpai pada wilayah-wilayah Kematan Wanaraya, Mekarsari, Rantau Badauh, Jejangkit dan Cerbon. Tanahtanah sulfat masam aktual dan tanah-tanah endapan marin yang dipengaruhi oleh air asin merupakan zona tidak berpotensi untuk komoditas hortikultura.

Zonasi komoditas perkebunan dengan potensi sedang tersebar pada tanah-tanah endapan tanggul sungai sepanjang aliran sunagi Barito dan sungai Alalak, tanahtanah endapan bekas meander sungai, serta sebagian tanah-tanah sulfat masam potensial dengan total luasan 61.121 ha.
Tabel 4. Ekstraksi Luasan Zonasi Komoditas Pertanian Unggulan di Batola

\begin{tabular}{|c|c|c|}
\hline Zona & Luas (ha) & Persen \\
\hline \multicolumn{3}{|l|}{ Pangan } \\
\hline P1 & 3.117 & 1,3 \\
\hline $\mathrm{P} 2$ & 153.229 & 63,8 \\
\hline P3 & 44.783 & 18,6 \\
\hline $\mathrm{N}$ & 39.233 & 16,3 \\
\hline Total & 240.354 & 100,0 \\
\hline \multicolumn{3}{|c|}{ Hortikultura } \\
\hline $\mathrm{H} 1$ & 3.118 & 1,3 \\
\hline $\mathrm{H} 2$ & 58.003 & 24,1 \\
\hline $\mathrm{H} 3$ & 38.975 & 16,2 \\
\hline $\mathrm{H} 4$ & 99.996 & 41,6 \\
\hline $\mathrm{N}$ & 40.262 & 16,8 \\
\hline Total & 240.354 & 100,0 \\
\hline \multicolumn{3}{|c|}{ Perkebunan } \\
\hline $\mathrm{K} 1$ & 61.121 & 25,4 \\
\hline K2 & 12.522 & 5,2 \\
\hline K3 & 137.720 & 57,3 \\
\hline K4 & 2.285 & 1,0 \\
\hline $\mathrm{N}$ & 26.706 & 11,1 \\
\hline Total & 240.354 & 100,0 \\
\hline
\end{tabular}

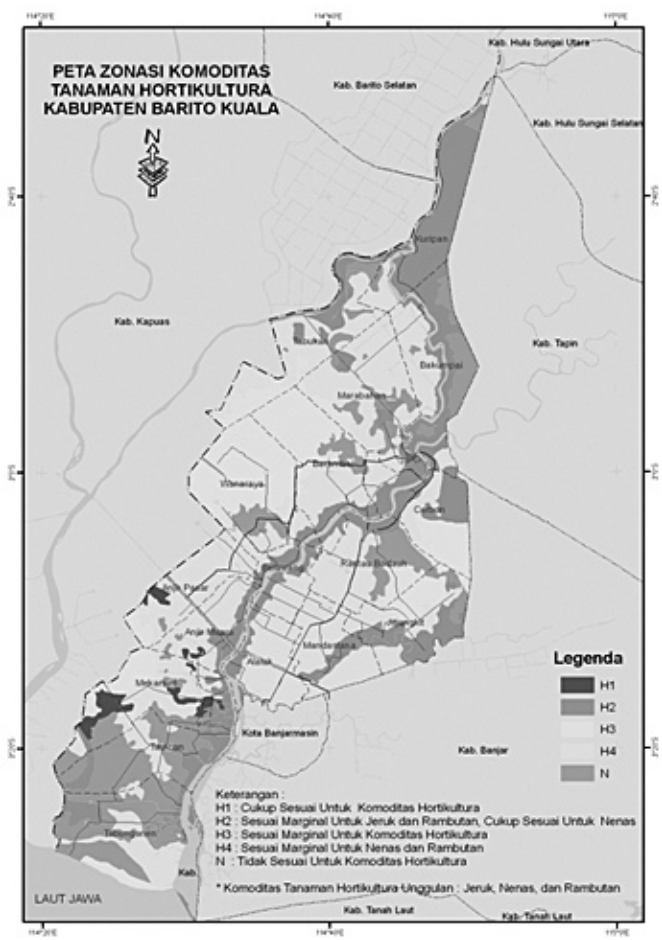

Gambar 3. Zonasi Komoditas Hortikultura 
Zona potensi rendah sampai sedang untuk komoditas perkebunan terdapat pada Kecamatan Tabunganen dan Kecamatan Tamban menempati areal yang tidak terlalu luas, yaitu 12.522 ha. Wilayah potensi rendah dijumpai pada daerah yang cukup luas dan tersebar merata hampir di seluruh wilayah studi dengan total luasan mencapai lebih dari 130.000 ha. Kemudian zona tidak berpotensi dijumpai pada tanah-tanah sulfat masam aktual dibagian selatan, bagian tengah dan bagian utara daerah studi.

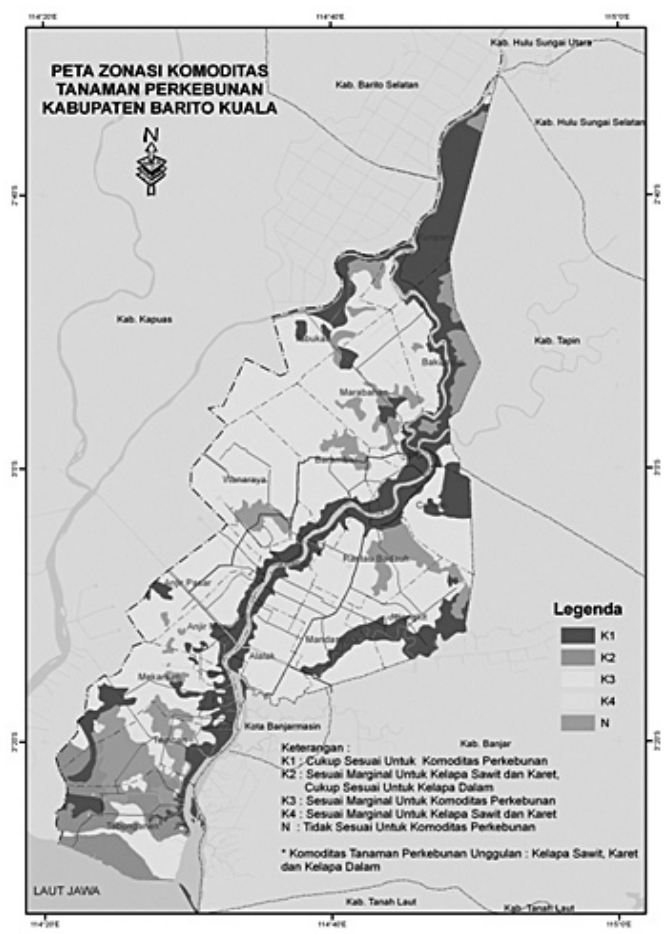

Gambar 4. Zonasi Komoditas Perkebunan

\section{KESIMPULAN}

1. Berdasarkan hasil interpretasi, pengamatan lapang dan didukung data hasil analisis laboratorium, Kabupaten Batola terbagi menjadi 3 fisiografi, yaitu (1) formasi gambut, (2) Formasi endapan Marin, (3) Formasi endapan Sungai dan terbagi menjadi 18 satuan lahan.

2. Tingkat kesesuaian lahan di Batola untuk usaha pertanian unggulan, baik pangan, hortikultura, maupun perkebunan sebagian besar masuk katagori sesuai marginal.

3. Tanaman perkebunan dan hortikultura mempunyai potensi yang baik untuk dikembangkan di Kabupaten Batola dari pada tanaman pangan

4. Faktor pembatas utama yang menjadi penghambat dalam usaha pertanian unggulan diantaranya adalah drainase/ genangan, bahaya sulfat masam, kemasaman, dan salinitas.

\section{DAFTAR PUSTAKA}

1. Hardjowigeno, S. dan Widiatmaka, 2001. Kesesuaian Lahan dan Prerencanaan Tataguna Tanah. Jurusan Tanah - Fak. Pertanian, IPB, Bogor.

2. FAO/CSR Staffs. 1983. Reconnaissance Land resource Sirvey 1: 250.000 Scale. Atlas Format Procedures. AGOF/ INS/78/006. Manual 4. Version 1. Centre for Soil Research, Bogor. Indonesia.

3. BPT (Balai Penelitian Tanah), 2003. Juknis: Evaluasi Lahan untuk Komoditas Pertanian. Puslitbangtanak - Deartemen Pertanian.

4. Widjaja-Adhi, IPG., K. Nugroho, Didi Ardi, S., dan A. Syarifuddin Karama. 1992. Sumberdaya Lahan Pasang Surut, Rawa dan Pantai: Potensi, Keterbatasan dan Pemanfaatan. Makalah Utama disajikan dalam Pertemuan Nasional Pengembangan Pertanian Lahan Pasang Surut dan Rawa. Bogor.

5. Dinas Pertanian, 2008. Profil Pertanian Tanaman Pangan dan Hortikultura Kabupaten Batola, Kalimantan Selatan

6. Lembaga Penelitian Tanah, 1973. Laporan survai tanah Delta Pulau Petak, Kalimantan Selatan. Ditjen Pertanian - Deptan. Bogor.

7. Sumawinata, B. 1999. Soil Chemical Profiles Developed from Pyrite-containing Sediments under Banjarese Agricultural Practices in South Kalimantan. South Asean Studies. Vol.36. No.4 (Jour.). 